\title{
Pengaruh Kompetensi SDM, Teknologi Informasi dan Komunikasi organisasi terhadap Kinerja Pegawai Dinas Lingkungan Hidup Kota Makassar
}

\author{
Maryam Odja $^{1,2}$ Nasir Hamzah² $^{2}$ Zainal Arifin $^{1}$ \\ ${ }^{1}$ Magister Ilmu Hukum Universitas Muslim Indonesia \\ 2 Koresponden Penulis, E-mail: maryam.odja@gmail.com
}

\begin{abstract}
ABSTRAK
Penelitian ini dilakukan dengan tujuan: (1) Untuk Mengetahui dan Menganalisis Pengaruh Kompetensi SDM terhadap Kinerja Pegawai Dinas Lingkungan Hidup Kota Makassar.. (2) Untuk Mengetahui dan Menganalisis Pengaruh Teknologi Informasi terhadap Kinerja Pegawai Dinas Lingkungan Hidup Kota Makassar. (3). Untuk Mengetahui dan Menganalisis pengaruh Komuniksi organisasi Terhadap Kinerja Pegawai Dinas Lingkungan Hidup Kota Makassar. Metode penelitian yang digunakan dalam penelitian ini adalah Analisis deskriptif dan analisis Regresi Linier Berganda, dengan jumlah sampel sebanyak 100 responden. Berdasarkan hasil analisis regresi linier berganda, maka Hasil penelitian menunjukkan bahwa (1). Kompetensi SDM berpengaruh positif dan signifikan Terhadap Kinerja Pegawai Dinas Lingkungan Hidup Kota Makassar (2) Teknologi Informasi berpengaruh positif dan signifikan Terhadap Kinerja Pegawai Dinas Lingkungan Hidup Kota Makassar (3). Komunikasi organisasi berpengaruh positif dan signifikan Terhadap Kinerja Pegawai Dinas Lingkungan Hidup Kota Makassar
\end{abstract}

Kata Kunci: Kompetensi SDM, Teknologi Informasi, Komunikasi Organisasi, Kinerja Pegawai.

\begin{abstract}
This research was conducted with the aim of: (1) To identify and analyze the influence of HR competence on the performance of the Makassar City Environmental Service employees. (2) To identify and analyze the effect of information technology on the performance of the Makassar City Environmental Service staff. (3). To Know and Analyze the influence of organizational communication on Employee Performance of the Environmental Service of Makassar City. The research method used in this research is descriptive analysis and multiple linear regression analysis, with a sample size of 100 respondents. Based on the results of multiple linear regression analysis, the results show that (1). Human resource competencies have a positive and significant effect on Employee Performance of the Makassar City Environmental Service 2) Information Technology has a positive and significant effect on Employee Performance of the Makassar City Environmental Service (3). Organizational communication has a positive and significant effect on Employee Performance of the Makassar City Environmental Servicet.
\end{abstract}

Keyword: HR Competence, Information Technology, Organizational Communication, Employee Performance. 


\section{PENDAHULUAN}

Undang-Undang Nomor 5 tahun 2014, menegaskan setidaknya terdapat 3 kompetensi kunci yang wajib dimiliki oleh pegawai ASN, yakni kompetensi teknis, kompetensi manajerial, dan kompetensi sosial kultural. Kompetensi teknis diukur dari tingkat dan spesialisasi pendidikan, pelatihan teknis fungsional, dan pengalaman bekerja secara teknis. Sedangkan kompetensi manajerial yang diukur dari tingkat pendidikan, pelatihan struktural atau manajemen, dan pengalaman kepemimpinan. Sementara kompetensi sosial kultural diukur dari pengalaman kerja berkaitan dengan masyarakat majemuk dalam hal agama, suku, dan budaya sehingga memiliki wawasan kebangsaan.Berdasarkan pemikiran tersebut, UndangUndang ASN mengatur mengenai penilaian kinerja yang bertujuan untuk menjamin objektivitas pembinaan PNS yang didasarkan sistem prestasi dan sistem karier. Undang-Undang ASN juga mengamanatkan agar penilaian kinerja PNS dilakukan secara objektif, terukur, akuntabel, partisipatif, dantransparan. Penilaian kinerja merupakan suatu proses rangkaian dalam Sistem Manajemen Kinerja PNS, berawal dari penyusunan perencanaan kinerja yang merupakan proses penyusunan Sasaran Kinerja Pegawai (SKP).

Dalam kaitannya dengan Teknologi informasi, tidak hanya pada teknologi komputer (perangkat keras dan perangkat lunak) yang akan digunakan untuk memproses dan menyimpan informasi, melainkan mencakup teknologi komunikasi untuk mengirim atau menyebarluaskan informasi. Penerapan TI tidak hanya pada sektor bisnis, tetapi pada sektor publik khususnya dalam memberikan pelayanan kepada masyarakat mutlak harus dibutuhkan. Sebagai contoh pengajuan perijinan, pembuatan Kartu Tanda Penduduk (KTP), pembuatan Surat Ijin Mengemudi (SIM) maupun informasi profil daerah. Seperti halnya perusahaan, pemerintah menghadapi masalah dalam penerapan TI. Teknologi merupakan salah satu faktor utama yang menggerakkan pertumbuhan ekonomi suatu negara. Dengan teknologi, maka kesejahteraan masyarakat dipastikan akan meningkat karena bisa meningkatkan efisiensi produktifitas dan nilai tambah suatu produk yang dihasilkan.

Teknologi Informasi saat ini berperan menjadi komponen pendukung utama pembangunan di berbagai bidang. Dalam pemerintahan, kemajuan TIK diadopsi untuk menunjang kinerja pemerintahan melalui program e-Government (e-Govt) (Martin, 1999). Teknologi Informasi dan Komunikasi akan berpengaruh terhadap peningkatan kinerja organisasi pemerintah. Menurut Dhata and Marijn (2016) kesiapan organisasi dalam peningkatan kinerja agar mencapai sasaran, hanya dapat dicapai apabila mendapatkan dukungan dari manajemen atau pimpinan pada khususnya.

Suatu teknologi informasi dapat memberikan dampak yang positif terhadap kinerja individual, maka teknologi tersebut harus dimanfaatkan dengan tepat dan harus mempunyai kecocokan dengan tugas yang didukung. Kinerja individual dalam penelitian adalah pencapaian serangkaian tugas individu dengan dukungan teknologi informasi.Kinerja yang semakin tinggi melibatkan kombinasi dari peningkatan efisiensi, efektivitas, produktivitas, dan peningkatan kualitas (Goodhue dkk. 1995). 
Dalam suatu organisasi diperlukan suatu sistem yang dapat menunjang kinerja organisasi tersebut.Pencapaian tujuan organisasi memerlukan kerjasama yang baik antar komponen di dalamnya. Kerjasama terbentuk karena adanya kesatuan persepsi tentang apa yang akan dicapai. Untuk itu diperlukan sekali adanya komunikasi yang baik antar anggota didalamnya, peran komunikasi dalam suatu organisasi dapat menciptakan hubungan kerja yang kondusif dalam rangka pencapaian tujuan organisasi.

Melalui komunikasi maka dapat memberikan keterangan tentang pekerjaan yang membuat pegawai dapat bertindak dengan rasa tanggung jawab pada diri sendiri dan pada waktu bersamaan dapat mengembangkan Kinerja organisasi (Wursanto, 2002). Adanya kerjasama yang harmonis ini diharapkan dapat meningkatkan Kinerja para pegawai karena komunikasi berhubungan dengan keseluruhan proses pembinaan perilaku manusia dalam organisasi. Kinerja dalam organisasi dapat mempengaruhi hasil kerja dan pencapaian tujuan komunikasi dan hubungan kerja yang terjadi dalam suatu instansi berkaitan dengan semangat melaksanakan pekerjaan. Komunikasi yang efektif dapat mencapai saling pengertian antara pegawai dan pimpinan sehingga terbentuk kondisi sosial yang dapat memotivasi pegawai untuk meningkatkan produktivitas kerjanya. Kinerja disini adalah pegawai secara lebih giat melaksanakan tugas-tugasnya, sehingga pekerjaan akan dapat diselesaikan lebih cepat dan lebih baik.

Komunikasi merupakan faktor utama untuk meningkatkan Kinerja. Dengan Kinerja yang tinggi pegawai akan dapat bekerja dengan perasaan senang dan bergairah sehingga mereka dapat berprestasi kerja dengan baik, sebaliknya apabila komunikasi organisasi mengalami hambatan atau distorsi, akan berakibat pada terjadinya mis komunikasi yang menghambat kelancaran pekerjaan dan pelayanan kepada masyarakat. Fenomena yang ada pada Kantor Dinas Lingkungan Hidup Kota Makassar memiliki komposisi pegawai sebanyak 189 ASN, dengan tingkat pendidikan yang terdiri dari S2 (25), S1 (54), Diploma (5), SMA (72), SMP (11), SD (22). Dengan komposisi ini, maka secara fenomenal, terdapat kesenjangan antara pegawai dengan tingkat pendidikan sarjana dan yang belum sarjana. Sehingga dengan komposisi ini maka berdasarkan arah dan semangat reformasi birokrasi pemerintah, maka dengan keadaan seperti ini harus dimanfaatkan dengan baik, sesuai dengan peran dan tugas masing - masing, sehingga pengelolaan SDM berbasis kinerja akan tercapai.

Sugiyanto dan Djoko Santoso (2018), dalam penelitiannya, menemukan bahwa kompetensi SDM berpengaruh positif dan signifikan terhadap kinerja pegawai. Dalam penelitian yang lain, Mutia Sari, Hasan Basri, Mirna Indriani. (2017) dan Rasipan Rasipan, Meli Andriyani (2017) juga menemukan bahwa Kompetensi Aparatur berpengaruh terhadap kinerja menejerial. Filliks Duwit (2015), dan Eva Silvani Lawasi dan Triatmono (2017) menemukan bahwa Kompetensi dan Komunikasi mempunyai pengaruh signifikan terhadap Kinerja Pegawai. Beberapa riset terkait yang disebutkan diatas, masih terdapat gap riset yang dilakukan oleh Sugiyanto dan Djoko Santoso (2018) yang menemukan bahwa sarana pendukung teknologi informasi berpengaruh negative terhadap kepuasan kerja, Sarana pendukung teknologi informasi tidak berpengaruhpositif terhadap kinerja SDM 


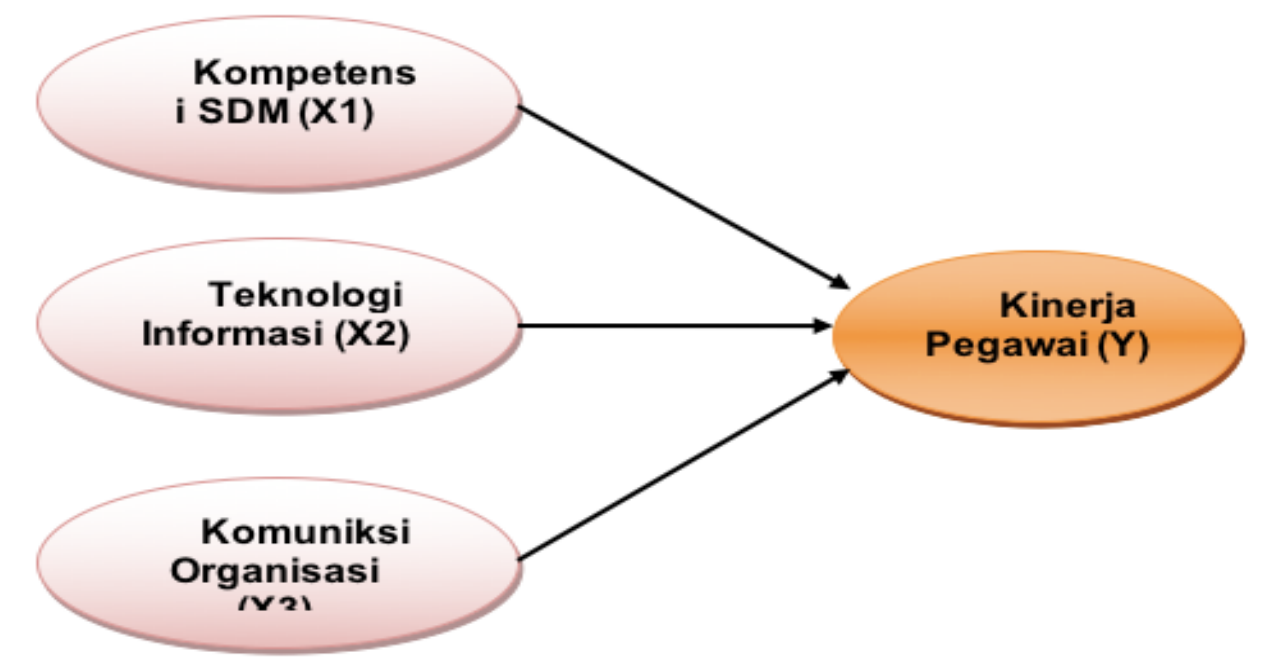

Gambar 1. Kerangka Konseptual

\section{Hipotesis}

1. Kompetensi SDM berpengaruh Positif dan signifikan terhadap kienerja pegawai Dinas Lingkungan Hidup Kota Makassar.

2. Teknologi Informasi berpengaruh Positif dan signifikan terhadap kienerja pegawai Dinas Lingkungan Hidup Kota Makassar.

3. Komunikasi organisasi berpengaruh Positif dan signifikan terhadap kienerja pegawai Dinas Lingkungan Hidup Kota Makassar.

\section{METODE PENELITIAN}

Pendekatan penelitian yang digunakan adalah metode penelitian kuantitatif yaitu menggambarkan dan menjelaskan pengaruh Kompetensi SDM, Teknologi Informasi, dan Komunikasi Organisasi Terhadap Kinerja ASN Dinas Lingkungan Hidup Kota Makassar. Penelitian ini akan dilaksanakan di Kantor Dinas lingkungan Hidup Kota Makassar yang berlokasi di Kompleks Gabungan Dinas-dinas Kota Makassar. Jl. Urip Sumihardjo, Kelurahan Maccini, Kecamatan Makassar. Adapun yang waktu yang digunakan selama pengumpulan data dan penyusunan tesis berkisar dua bulan lamanya dimulai pada bulan Mei sampai dengan bulan Juli 2020.

\section{Pengujian Hipotesis}

\section{Uji Validitas dan Reliabelitas}

Untuk uji validitas yaitu dengan mengkorelasikan antar skor item instrument dalam dalam suatu faktor dan mengkorelasikan skor faktor dengan skor total (Sugiyono, 2013:207). Selanjutnya hasil dari perhitungan tersebut di bandingkan dengan nilai $r$ table.Apabila $r$ hitung $>r$ table, maka item tersebut dapat dinyatakan valid. Sebaliknya jika $\mathrm{r}_{\text {hitung }}<\mathrm{r}_{\text {table, }}$ maka item tersebut dinyatakan tidak valid.

Sedangkan reliable atau handal merupakan indeks yang menunjukan sejauh mana suatu alat ukur dapat dipercaya atau diandalkan untuk mengukur berbagai aspek dari suatu variable penelitian. Suatu instrument dikatakan reliable atau handal apabila memiliki koefisien reliabelitas (a) sebesar 0,60 atau lebih (arikunto, 2006). 


\section{Uji Asumsi klasik}

\section{a. Uji Normalitas}

Sugiyono (2011:10) dalam melakukan uji regresi diisyaratkan agar data yang digunakan normal. Pada penelitian ini untuk mengetahui normalitas distribusi dapat dilakukan dengan melihat nilai residual pada model regresi yang akan diuji. Jika residual berdistribusi normal maka nilai sebaran data akan terletak disekitar garis lurus. Pengujian normalitas dalam penelitian ini menggunakan uji Histogram dan uji normal P Plot.

\section{b. Multikolinieritas}

Uji Multikoliniearitas bertujuan untuk menguji apakah model regresi ditemukan adanya korelasi bebas (independen). Deteksi terhadap ada tidaknya Multikoliniearitas yaitu dengan menganalisis matriks korelasi variabel bebas. Keberadaan Multikoliniearitas dapat dilihat melalui nilai VIF (Variance Inflation Factors) atau nilai toleransinya.Keberadaan Multikoliniearitas dapat diketahui apabila nilai VIF $>10$ atau secara kebalikannya dengan melihat nilai toleransinya $<0,1$. Bila nilai VIF dari masing-masing variabel $<10$ atau secara kebalikannya nilai toleransinya $>$ 0,1 maka dapat dikatakan tidak terjadi Multikolinearitas atau hubungan yang terjadi antar variabel bebas dapat ditoleransi sehingga tidak akan mengganggu hasil regresi.

\section{c. Heteroskedastisitas}

Uji Heterokedastisitas dilakukan untuk menguji apakah dalam model regresi terjadi ketidaksamaan varians dari residual satu pengamatan ke pengamatan lain. Dalam regresi, salah satu asumsi yang harus dipenuhi adalah bahwa varians dari residual yang disebut homokedastisitas.Dasar dalam melihat suatu angket terjadi heterokedastisitas ataupun tidak yaitu jika nilai signifikan > 0,05 maka dapat dikatakan tidak terjadi heterokedastisitas dan sebaliknya jika nilai signifikan $<0,05$ maka terjadi heterokedastisitas.

\section{Uji Determinasi (R2)}

Koefisien determinasi pada intinya mengukur kemampuan model dalammenerangkan variasi variabel dependen.Nilai koefisien determinasi adalah antaranol dan satu.Nilai $\mathrm{R}^{2}$ yang kecil berarti kemampuan variabelvariabel independendalam menjelaskan variasi variabel dependen amat terbatas.Nilai yang mendekatisatu berarti variabel-variabel independen memberikan hampir semua informasiyang dibutuhkan untuk memprediksi variasi variabel dependen. Jika dalam suatumodel terdapat lebih dari dua variabel independen, maka lebih baik menggunakannilai adjusted $\mathrm{R}^{2}$. Hal tersebut dikarenakan nilai adjusted $\mathrm{R}^{2}$ dapat naik atau turunapabila ada penambahan variabel independen dalam model, tidak seperti $\mathrm{R}^{2}$ yangselalu meningkat apabila terjadi penambahan variable independen yang tidakmempedulikan apakah variabel yang ditambahkan tersebut berpengaruh secarasignifikan terhadap variabel dependen (Ghozali, 2011). 


\section{Uji F (Uji Simultan)}

Output hasil uji F dilihat untuk mengetahui pengaruh variabel independenterhadap variabel dependen (Gujarati, 2007).Pengambilan keputusan yaitu berdasarnilai probabilitas (F-Statistic) $<0.05$ atau 5\% maka dapat disimpulkan secara bersama-sama (simultan) variabel independen berpengaruh terhadap variabel dependen. Namun apabila nilaiprobabilitas (F-statistic) > 0,05 atau 5\% maka dapat disimpulkan bahwa semuavariabel independen tidak berpengaruh terhadap variabel dependen.

\section{Uji t (Uji Parsial)}

Menurut Kuncoro (2011:105) uji statistik t menunjukkan seberapa jauh satu variabel penjelas secara individual dalam menerangkan variasi variabel terikat. Hipotesis yang akan diuji adalah sebagai berikut :

$\mathrm{H}_{0}: b_{\mathrm{i}}=0$, maka $\mathrm{X}_{\mathrm{i}}$ tidak berpengaruh terhadap $\mathrm{Y}$

$\mathrm{H}_{1}: b_{i} \neq 0$, maka $X_{i}$ berpengaruh terhadap $Y$

dengan kriteria pengujian:

a) Jika nilai signifikasi $>0,05$, berarti tidak ada pengaruh yang signifikan antara variabel bebas (Kompetensi SDM, Teknologi Informasi, dan Komunikasi Organisasi terhadap Kinerja ASN).

b) Jika nilai signifikasi < 0,05, berarti ada pengaruh yang signifikan antara variabel bebas (Kompetensi SDM, Teknologi Informasi, dan Komunikasi Organisasi terhadap Kinerja ASN).

\section{HASIL PENELITIAN DAN PEMBAHASAN}

\section{Hasil}

\section{Uji Asumsi Klasik}

\section{a. Uji Normalitas}

Uji normalitas dapat digunakan untuk melihat apakah nilai residual terdistribusi normal atau tidak.Model regresi yang baik adalah memiliki nilai residual yang terdistribusi normal. Jadi uji normalitas bukan dilakukan pada masing-masing variabel tetapi pada nilai residualnya.Sering terjadi kesalahan yang jamak yaitu bahwa uji normalitas dilakukan pada masing-masing variabel. Hal ini tidak dilarang tetapi model regresi memerlukan normalitas pada nilai residualnya bukan pada masing-masing variabel penelitian.

Uji normalitas dapat dilakukan dengan uji histogram, uji normal P Plot, uji Chi Square, Skewness dan Kurtosis atau uji Kolmogorov Smirnov. Tidak ada metode yang paling baik atau paling tepat. Tipsnya adalah bahwa pengujian dengan metode grafik sering menimbulkan perbedaan persepsi di antara beberapa pengamat, sehingga penggunaan uji normalitas dengan uji statistik bebas dari keragu-raguan, meskipun tidak ada jaminan bahwa pengujian dengan uji statistik lebih baik dari pada pengujian dengan metode grafik dibawah ini

Dasar pengambilan keputusan, Jika data menyebar disekitar garis diagonal dan mengikuti arah garis, maka model regresi memenuhi asumsi normalitas. Dengan 
demikian karena grafik memenuhi asumsi maka model regresi memenuhi syarat uji normalitas (lihat lampiran Statistik).

\section{b. Uji Heteroskedastisitas}

Uji heteroskedastisitas adalah untuk melihat apakah terdapat ketidaksamaan varians dari residual yang satu ke pengamatan yang lain. Model regresi yang memenuhi persyaratan adalah di mana terdapat kesamaan varians dari residual satu pengamatan ke pengamatan yang lain tetap atau disebut homoskedastisitas.

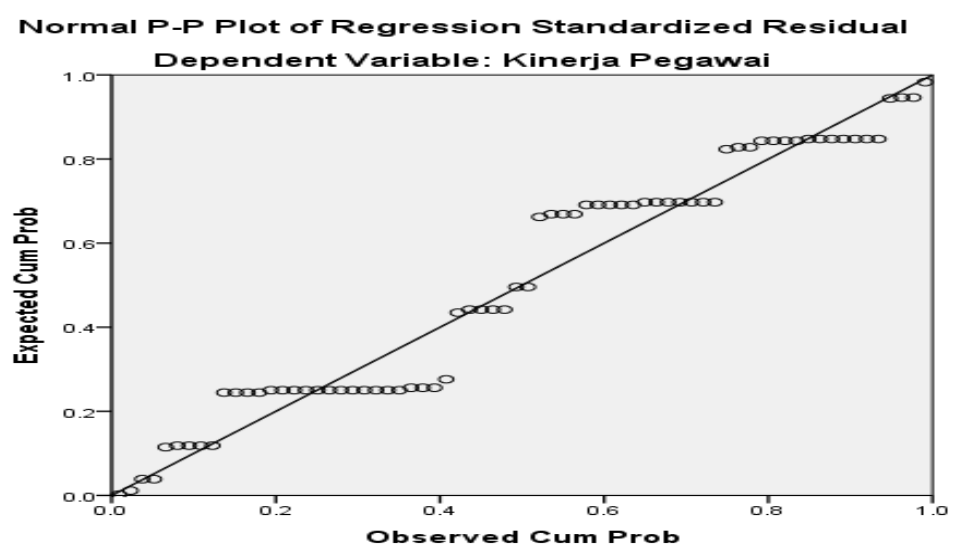

Deteksi heteroskedastisitas dapat dilakukan dengan metode scatter plot dengan memplotkan nilai ZPRED (nilai prediksi) dengan SRESID (nilai residualnya). Model yang baik didapatkan jika tidak terdapat pola tertentu pada grafik, seperti mengumpul di tengah, menyempit kemudian melebar atau sebaliknya melebar kemudian menyempit. Uji statistik yang dapat digunakan adalah uji Glejser, uji Park atau uji White. Beberapa alternatif solusi jika model menyalahi asumsi heteroskedastisitas adalah dengan mentransformasikan ke dalam bentuk logaritma, yang hanya dapat dilakukan jika semua data bernilai positif. Atau dapat juga dilakukan dengan membagi semua variabel dengan variabel yang mengalami gangguan heteroskedastisitas.Tampak pada gambar diatas menunjukkan tidak terjadinya heteroskedastisitas. Ini ditandai dengan tidak adanya pola yang jelas, serta titik menyebar diatas dan dibawah angka 0 pada sumbu $Y$.

\section{c. Uji Multikolinieritas}

Menurut Ghozali (2016) pada pengujian multikolinearitas bertujuan untuk mengetahui apakah model regresi ditemukan adanya korelasi antar variabel independent atau variable bebas.Efek dari multikolinearitas ini adalah menyebabkan tingginya variabel pada sampel. Hal tersebut berarti standar error besar, akibatnya ketika koefisien diuji, t-hitung akan bernilai kecil dari t-tabel. Hal ini menunjukkan tidak adanya hubungan linear antara variabel independen yang dipengaruhi dengan variabel dependen. Untuk menemukan terdapat atau tidaknya multikolinearitas pada model regresi dapat diketahui dari nilai toleransi dan nilai variance inflation factor (VIF). Nilai Tolerance mengukur variabilitas dari variabel bebas yang terpilih yang tidak dapat dijelaskan oleh variabel bebas lainnya. Jadi nilai tolerance rendah sama dengan nilai VIF tinggi, dikarenakan VIF $=1 /$ tolerance, dan menunjukkan 
terdapat kolinearitas yang tinggi. Nilai cut off yang digunakan adalah untuk nilai tolerance 0,10 atau nilai VIF diatas angka 10.

\section{d. Uji Multikolinieritas}

Tabel. 14. Hasil Pengujian Multikolinieritas

Coefficients ${ }^{a}$

\begin{tabular}{|ll|r|r|}
\hline \multirow{2}{*}{ Model } & & \multicolumn{2}{|c|}{ Collinearity Statistics } \\
\cline { 3 - 4 } & (Constant) & Tolerance & \multicolumn{1}{|c|}{ VIF } \\
& Kompetensi SDM & .849 & 1.178 \\
& Teknologi Informasi & .724 & 1.380 \\
& Komunikasi Organisasi & .807 & 1.240 \\
\hline
\end{tabular}

a. Dependent Variable: Kemauan Membyr Pjk

Berdasarkan tabel diatas maka dapat dikatakan bahwa model regresi memenuhi syarat uji multikolineritas. Sebagaimana dilihat pada kolom VIF hasil uji SPSS 24 yang berada disekitar angka 1 dan kolom tolerance mendekati angka 1. (Ghozali, 2002:65). Dalam model regresi yang baik seharusnya tidak terjadi korelasi diantara variabel independent. Uji multikolinearitas dilakukan dengan melihat nilai toleransi lebih besar dari 10\%(0,10) dengan Variace Inflation Factor(VIF) kurang dari 10, maka tidak terdapat multikolinearitas.

Selanjutnya akan kita pastikan dengan melihat cara deteksi multikolinearitas lainnya, yaitu berdasarkan nilai standar error dan koefisien beta regresi parsial. Dalam tabel coefficient nilai standar error kurang dari satu, yaitu $\mathrm{X}_{1}=.060, \mathrm{X}_{2}=.075$, dan $\mathrm{X}_{3}$ $=.064$, dimana semua nilainya kurang dari satu.Serta nilai koefisien beta juga kurang dari satu dimana $\mathrm{X}_{1}=0,484, \mathrm{X}_{2}=0,199$, dan $\mathrm{X}_{3}=0,380$. Maka dapat dikatakan bahwa nilai standar error rendah dan multikolinearitas tidak terdeteksi.

\section{Analisis Regresi Linier Berganda}

Tabel.15. Analisis Regreasi Linier Berganda

\begin{tabular}{|c|c|c|c|c|c|c|}
\hline \multicolumn{7}{|c|}{ Coefficients $^{a}$} \\
\hline \multirow{2}{*}{\multicolumn{2}{|c|}{ Model }} & \multicolumn{2}{|c|}{$\begin{array}{l}\text { Unstandardized } \\
\text { Coefficients }\end{array}$} & \multirow{2}{*}{$\begin{array}{c}\text { Standardized } \\
\text { Coefficients } \\
\text { Beta }\end{array}$} & \multirow[b]{2}{*}{$\mathrm{t}$} & \multirow[b]{2}{*}{ Sig. } \\
\hline & & B & Std. Error & & & \\
\hline \multirow[t]{5}{*}{1} & (Constant) & .115 & .326 & & .353 & .725 \\
\hline & Kompetensi SDM & .442 & .060 & .484 & 7.300 & .000 \\
\hline & Teknologi Informasi & .208 & .075 & .199 & 2.773 & .007 \\
\hline & Komunikasi Organisasi & .360 & .064 & .380 & 5.579 & .000 \\
\hline & $\begin{array}{l}R=801 \\
R^{2}=641\end{array}$ & \multicolumn{5}{|c|}{$\begin{array}{l}\text { F Hitung }=57.186 \\
\text { Sig }=0,000\end{array}$} \\
\hline
\end{tabular}

Hasil Olahan SPSS-20. 2020

Berdasarkan tabel diatas, maka persamaan regresi dapat dilihat sebagai berikut:

$$
Y=0.115+0,442 X_{1}+0,208 X_{2}+0,360 X_{3}
$$

- Nilai konstan yaitu b nol(b0) =0,115, mempunyai arti bahwa, apabila variabel Kompetensi SDM $\left(\mathrm{X}_{1}\right)$, variabel Teknologi informasi, (X2), dan variabel Komunikasi Organisasi (X3) tidak mengalami perubahan maka Kinerja Pegawai sebesar 0,115. 
- Koefisien regresi Variabel Kompetensi SDM $\left(X_{1}\right)$ sebesar 0,442, hal ini berarti bahwa apabila Kompetensi SDM ditingkatkan menjadi 1 satuan atau unit, maka kinerja pegawai juga akan meningkat. sebesar 44,2, dengan asumsi variabel variabel X2 dan X3 bernilai konstan.

- Koefisien regresivariabel Teknologi informasi, (X2) sebesar 0.208, hal ini berarti bahwa apabila teknologi informasi ditingkatkan menjadi 1 unit atau satuan, maka kinerja pegawai juga akan meningkat sebesar 20,8 dengan asumsi Variabel X1 dan X3 bernilai konstan.

- Koefisien regresi variabelKomunikasi organisasi, (X3) sebesar 0.360, hal ini berarti bahwa apabila komunikasi organisasi ditingkatkan sebesar 1 unit atau satuan, maka akan meningkatkan kinerja pegawai sebesar 36,0 dengan asumsi Variabel X1 dan X2 bernilai konstan.

- Besarnya nilai koefisien korelasi (R) adalah 0.801, hal ini menunjukan bahwa besarnya hubungan antara variabel independent $\mathrm{X} 1, \mathrm{X} 2$, dan X3, dengan Variabel Dependen (Y) yaitu Kinerja Pegawaisebesar 0.801. Hal ini berarti bahwa besarnya pengaruh variabel independen terhadap variabel dependen adalah sebesar 80,1 .

- Besarnya nilai koefisien determinasi $\left(\mathbf{R}^{2}\right)$ adalah 0.641, hal ini menunjukan bahwa besarnya pengaruh variabel independen $(\mathbf{X})$ terhadap Kinerja Pegawaidi Kantor Dinas Lingkungan Hidup Kota Makassar sebesar 0.641 atau $(64,1)$ dan sisanya sebesar 0.351 atau 35,9 dipengaruhi oleh faktor atau variabel lain yang tidak dimasukan dalam model penelitian ini.

\section{Pengujian Hipotesis}

\section{a. Uji F (Uji Simultan)}

Pengujian ini dimaksudkan untuk mengetahui bagaimana variabel independent (bebas) yang terdiri dari Kompetensi SDM, Teknologi informasi, dan Komunikasi Organisasisecara simultan (bersama sama) berpengaruh terhadap Kinerja PegawaiKantor Dinas Lingkungan Hidup Kota Makassar.

Dalam tabel regresi diperoleh F-hitung $=57.186>F_{\text {tabel }}=3,09$, serta memiliki tingkat signifikansi 0,000. Karena probabilitas 0,000 jauh lebih kecil dari 0,05, maka dapat dikatakan bahwa model regresi yang telah digunakan dapat meningkatkan Kinerja Pegawai. Atau dapat dikatakan bahwa variabel Kompetensi SDM, Teknologi informasi, dan Komunikasi Organisasisecara bersama-sama berpengaruh terhadapKinerja Pegawai.

\section{b. Uji t (Uji Parsial)}

Untuk mengetahui pengaruh secara parsial dari masing-masing variabel independen Kompetensi SDM, Teknologi informasi, dan Komunikasi Organisasi, terhadap Kinerja Pegawaipada Kantor Dinas Lingkungan Hidup Kota Makassar,maka berikut ini akan dijelaskan sebagai berikut:

\section{1). Variabel Kompetensi SDMX}

Berdasarkan hasil penelitian yang menguji pengaruh Kompetensi SDMterhadap Kinerja Pegawaidiperoleh nilai $\mathrm{t}$ hitung $=5.598>\mathrm{t}$ tabel $=1.660$ dengan tingkat signifikansi sebesar 0,000, lebih kecil jika dibandingkan dengan tingkat $a=5 \%$. 
Hasil ini menunjukkan bahwa secara perhitungan statistik terdapat Pengaruh Kompetensi SDMterhadap kinerja Pegawai.Dengan demikian hipotesis pertama yang menyatakan bahwa Kompetensi SDMberpengaruh positif dan signifikan terhadap Kinerja PegawaiPada Kantor Dinas Lingkungan Hidup Kota Makassarterbukti (H1 diterima).

\section{2). Variabel Teknologi informasi $X_{2}$}

Berdasarkan hasil pengujianstatistik ditemukan bahwaTeknologi informasi berpengaruh terhadap Kinerja Pegawaipada Kantor Dinas Lingkungan Hidup Kota Makassardengan nilai $\mathrm{t}$ hitung $=2.773>\mathrm{t}$ - tabel $=1.660$ dengan tingkat signifikansi sebesar 0,007 lebih kecil jika dibandingkan dengan tingkat $a=5 \%$. Hasil ini menunjukkan bahwa secara perhitungan statistik Teknologi informasiberpengaruh terhadapkinerja Pegawai. Dengan demikian hipotesis kedua yang menyatakan bahwa Teknologi informasipajak berpengaruh positif signifikan terhadap Kinerja Pegawai Pada Kantor Dinas Lingkungan Hidup Kota Makassar terbukti (H2 diterima).

\section{3). Variabel Komunikasi Organisasi $X_{3}$}

Temuan penelitian, menemukan bahwa nilai $t_{\text {hitung }}=5.579>t$ tabel $=1.660$, dengan tingkat signifikansi sebesar 0,000, lebih kecil jika dibandingkan dengan tingkat $a=$ 5\%. Hasil ini menunjukkan bahwa secara perhitungan statistik Komunikasi Organisasi berpengaruh terhadap kinerja Pegawai. Dengan demikian hipotesis ketiga yang menyatakan bahwa Komunikasi Organisasi berpengaruh terhadap Kinerja Pegawai pada Kantor Dinas Lingkungan Hidup Kota Makassar, terbukti (H3 diterima.

\section{Pembahasan}

\section{Pengaruh Kompetensi SDM terhadap Kinerja}

Berdasarkan hasil penelitian diperoleh bahwa Kompetensi SDM berpengaruh positif dan signifikan terhadap Kinerja Pegawai Dinas lingkungan hidup Kota Makassar. Nilai koefisien regresi sebesar 0,442, berarti bahwa setiap terjadi peningkatan dalam Kompetensi SDM, maka akan meningkatkan Kinerja pegawai Pegawai pada Kantor Dinas lingkungan hidup Kota Makassar sebesar 44,2.Variabel kompetensi SDM dalam penelitin ini menggunakan beberapa indikator yaitu kompetensi teknis, kompetensi menejerial, dan kompetensi sosial. Indikator Pertama Kompetensi Teknis. Indikator ini menggunakan teori induk dari Spencer dan Spencer dalam Hutapea danThoha (2008:28-30), kemudian Permenpan-RB nomor 38 tahun 2017 tentang standar Kompetensi Jabatan ASN.Masing-masing indikator dijelaskan sebagai berikut. Indikator pertama, Kompetensi Teknis.Baik teori maupun Peraturan Menteri ini memiliki full kesamaan definisi kompetensi teknis. Sedangkan menurut Hutapea dan Thoha (2008:3) Kompetensi teknis atau fungsional (tehnical/functional competences) ataudapat juga disebut dengan istilah hard skills/hard competency (kompetensi keras).Konsentrasi kompetensi teknis adalah padapekerjaan, yaitu untuk menggambarkan tanggung jawab, tantangan, dan sasarankerja yang harus dilakukan atau dicapaioleh pegawai agar dapat berprestasi atau meningkatkan kinerjanya. Kemudian Dalam teori kompetensi yang dikemukakan oleh Endang Komara (2018), Komptensi Teknis disebut juga dengan hard competency atau jenis 
kompetensi yang berkaitan dengan kemampuan fungsional atau teknis suatu pekerjaan. Dengan kata lain, kompetensi Pegawai ASN disini berkaitan dengan seluk-beluk teknis yang berkaitan dengan pekerjaan yang ditekuni. Contoh hard competency adalah electrical engineering, marketing research, finansial analysis, manpower planning, dan lain-lain. Berdasarkan hasil tanggapan pegawai terkait dengan kompetensi teknis yang dijabarkan pada tingkat pendidikan dan pelatihan, serta dorongan orgnasasi, menunjukan bahwa kompetensi SDM terbentuk oleh adanya pendidikan dan pelatihan yang dilakukan oleh organisasi, dan adanya motivasi dari pimpinan organisasi dalam memberikan ruang dalam peningkatan kompetensi pegawai.

\section{Pengaruh Teknologi informasi terhadap Kinerja}

Berdasarkan hasil penelitian yang menguji pengaruh Teknologi informasi terhadap kinerja Pegawai Dinas Lingkungan HidupKota Makassar ditemukan bahwa Teknologi informasi berpengaruh positif dan signifikan terhadap kinerja pegawai Hasil Penelitian ini menunjukkan bahwa hipoteis statistik menyatakan Teknologi informasi berpengaruh terhadap kinerja Pegawai. Dengan demikian hipotesis kedua dalam penelitian ini dapat diterima,terbukti (H2 diterima).Teknologi informasi dalam penelitian ini menggunakan indikator yang teorinya ditemukan oleh Davis (1989), dan sangat popular dalam riset-riset adopsi teknologi informasi. Kemudian Thompson (1991) dan Vankatesh (2003). Mitja Dečman and Maja Klun (2015)mengemukakan bahwa Pentingnya solusi TI untuk kinerja administrasi publik yang lebih baik diakui secara luas di dunia saat ini. Bahkan e-government telah melampaui masa kecilnya dan merupakan pabrik penting dalam memastikan efisiensi dan efektivitas administrasi publik. Fitrah (2020) mengemukakan Teknologi menawarkan kemudahan, kecepatan, dan efisiensi pekerjaan lengkap dengan tantangan-tantangannya.

Indikator yang digunakan dalam variabel ini adalah kebermanfaatan, ekspektasi kinerja, Kemudahan, dan kemampuan Pengguna. Filosofi dari teori ini adalah apabila suatu adopsi teknologi itu dianggap bermanfaaat, maka akan digunakan oleh pemakainya, begitupula dengan ekspektasi kinerja, bila menggunakan teknologi itu dapat memberikan jaminan peningkatan kinerja, dan bila teknologi itu mudah digunakan, maka akan mempengaruhi persepsi penggunannya. Menurut Davis (1989) dalam teori Technology Acceptance Model (TAM) menjelaskan bahwa faktor penerimaan penggunaan sistem teknologi informasi dipengaruhi oleh persepsi kemudahan penggunaan (Perceived Ease of Use) dan persepsi kegunaan (Perceived Usefulness) (Davis, 1989). Pengguna teknogi akan mempunyai minat menggunakan teknologi (Behavioral Intention) jika merasa sistem teknologi bermanfaat dan mudah digunakan (Jogiyanto, 2007).

Berdasarkan tanggapan responden, maka variabel pemanfaatan teknologi memiliki tingkat responsifitas, dan memiliki nilai koefisien regresi yang rendah dibandingkan dengan dua variabel lainnya.Hal ini berarti bahwa teknologi informasi memiliki peran yang sangat strategis dalam menunjang aktifitas organisasi dalam situasi dan kondisi bagaimanapun. Indikator pertama, yaitu kebermanfaatan hasil tanggapan responden menunjukan bahwa responsifitas pegawai yang menunjukan bahwa 
teknologi informasi adalah kebutuhan organisasi dan dapat memberikan manfaat dalam menunjang kinerja pegawai atau organisasi.

Temuan dalam indikator ini sejalan dengan penelitian Jumnawati (2020), yang menemukan bahwa persepsi kebermanfatan memberikan pengaruh terhadap penggunaan e-faktur di KPP Maros, Fitrah (2020) juga menemukan hal sama bagi pengguna SIDJP di KPP Makassar Selatan, temuan yang sama juga dari Afandi Bahari (2020), dan Verawaty (2020) yang meneliti penggunaan aplikasi e-faktur di Kantor pelayanan Pajak Pratama Makassar Barat. Indiaktor selanjutnya adalah ekspektasi kinerja. Indikator ini memiliki nilai rata-rata tanggapan dalam kriteria Baik. Hal ini sejalan dengan pendapat Venkantesh et al. (2003) mendefinisikan ekspektasi kinerja sebagai persepsi dimana pengguna mau untuk menampilkan aktivitas karena dapat meningkatkan nilai hasil seperti peningkatan kinerja, gaji atau promosi. Seorang pegawai yang memiliki ekspektasi kinerja yang tinggi akan memiliki minat pemanfaatan sistem teknologi informasi yang tinggi pula karena pegawai tersebut merasa akan ada nilai lebih dari kinerja apabila dibantu dengan penggunan sistem teknologi informasi. Hal ini sejalan dengan penelitian Azis (2019), menemukan bahwa semakin meningkat ekspektasi kinerja, maka akan meningkatkan minat pengguna Indihome di Kota Makassar. Ni Made Harista Dwi Anggreni (2020), juga menmukan bahwa peningkatan ekspektasi kinerja telah memberikan dampak pada penggunaan sistim informasi Akuntansi. IwanDjemma (2020) menemukan bahwa ekspektasi kinerj berpengaruh positif dan signifikan terhadap kinerja pegawai.Perkembangan teknologi informasi memberikan banyak pengaruh terhadap sistem informasi akuntansi karena ada digitalisasi informasi (Yuhelson et al., 2020).Penggunaan teknologi komputer dan internet merupakan salah satu bentuk teknologi informasi yang mampu mengubah proses data secara manual menjadi secara digital dan otomatis (Suhardiyah \& Waryanto, 2014).

Indikator selanjutnya adalah kemudahan, dan kemampuan yang masing-masing memiliki satu item pernyatan dengan nilai rata-rata 3,82 dan 4,2. Jawaban responden menunjukan bahwa penggunaan teknologi informasi pada Kantor Dinas Lingkungan Hidup Kota Makassar adalah sebuah kebutuhan, sehingga pegawai harus menguasinya. Meskipun penelitian ini mereplikasi variabel dalam konstruk TAM secara parsial, namun dapat membuktikan secara faktual bahwa asumsi kemudahan sebagai alasan utama terhadap penggunaan teknologi informasi adalah sesuatu yang rasional, sehingga dapat dikatakan bahwa mudah adalah pengsifatan dari pengetahuan, dan pengalaman, pengamatan, dan daya serap eksternal. Jika diaplikasikan dalam penggunaan berbagai aplikasi di Dinas Lingkungan Hidup Kota Makassar, maka maksudnya pegawai meyakini kalau teknologi informasi tersebut mudah dalam penggunaannya sehingga tidak memerlukan usaha keras dan akan terbebas dari kesulitan. Penelitian yang sejalan dengan temuan ini adalah temuan dari Affandi Bahari (2020), yang menemukan efektifitas penggunaan aplikasi dibidang perpajakan di KPP Maros, dan Fitrah Maula (2020), dalam penelitian mengena SIDJP di KPP Makassar Selatan Irma (2017), yang meneliti aplikasi e-filing di KPP Makassar Selatan, dan Arga (2019) juga Jumnawaty (2020) meneliti tetang aplikasi e-biling di KPP Maros.Dimana hasil penelitian tersebut menunjukan hubungan dan korelasi positif signifikan terhadap penggunaan aplikasi teknologi. 
Implikasi dari temuan ini adalah, bahwa suatu aplikasi teknologi akan menarik daya penggunanya jika mudah menggunakannya, dan memberikan manfaat bagi penggunnya. Jawaban responden dalam variabel ini dapat merepresentasikan hukum pengadopsian teknologi, dalam berbagai lapangan riset, dan berbagai medan lingkungan bisnis.

\section{Pengaruh Komunikasi Organisasi Terhadap Kinerja}

Berdasarkan hasil penelitian yang menguji pengaruh Komuniksi Organisasi terhadap kinerja Pegawai Dinas Lingkungan HidupKota Makassar ditemukan bahwa Komunikasi organisasi berpengaruh positif dan signifikan terhadap kinerja pegawai Hasil Penelitian ini menunjukkan bahwa hipoteis statistik menyatakan Komunikasi Organisasi berpengaruh terhadap kinerja Pegawai. Dengan demikian hipotesis Ketigadalam penelitian ini dapat diterima,terbukti (H2 diterima).

Hasil penelitian ini juga menjustifikasi peran positif dari Manajemen partisipatif dewasa ini yang telah menjadi kebutuhan dari para manajer dan pemimpin di era globalisasi. Maknanya adalah bahwa berbagai solusi dari persoalan-persoalan manajemen dan kepemimpinan terletak pada pemikiran bersama (shared views). Kajian terhadap aspek partisipasi di alam terbuka mempunyai makna tersendiri dalam mengembangkan manajemen partisipasif yang merupakan bagian tak terpisahkan dari pengembangan kepemimpinan yang demokratis.Partisipasi merupakan tahapan yang dicapai dalam komunikasi yang bebas dan terbuka (genuine communication and dialogue), di mana semua orang merasa bebas mengemukakan pendapatnya dan bebas pula memberikan pendapat terhadap pendapat atau pemikiran orang lain. Pada tahap demikian, manajemen partisipatif (partisipative management) dapat terwujud yang membuka peluang lebih banyak orang ambil bagian dalam proses pengambilan keputusan dari organisasi atau instansi bersangkutan.

Dalam komunikasi yang bersifat terbuka, dapat terjadi pergeseran/pengembangan keterampilan dalam pemahaman (inquiry), refleksi (reflection) dan interaksi verbal (dialogue). Semakin intensif proses komunikasi berlangsung, semakin meningkat kedalaman dan keterbukaan dari fihakfihak yang berkomunikasi tersebut. Pada gilirannya, visi bersama (shared vision) akan terbangun dengan tingkat partisipasi yang tinggi untuk mewujudkannya secara bersama-sama. Visi dan misi dari suatu organisasi (instansi) tidak akan dapat diwujudkan tanpa partisipasi aktif dan efektif dari semua anggota/karyawannya. Karenanya, partisipasi tersebut mutlak ditumbuhkembangkan melalui komunikasi yang terbuka (genunie communication and dialogues).

\section{KESIMPULAN}

1. Kompetensi SDM berpengaruh positif dan signifikan terhadap kinerja pegawai. Temuan membenarkan teori dan riset pendukungnya yang menjadi dasar dalam penelitian ini.Hasil penelitian ini juga dapat menjawab permasalahn dan hipotesis penelitian.

2. Teknologi Informasi berpengaruh positif dan signifikan terhadap kinerja pegawai Dins lingkunga hidup Kota Makassar. Hasil penelitian ini juga menjawab masalah dan tujuan dalam penelitian ini, maupun hipotesis kedua 
yang menyatakan bahwa teknologi informasi berpengaruh positif dan signifikan terhadap kinerja Pegawai dapat dibuktikan secara statistik.

3. Komuniksi organisasi berpengaruh terhadap kinerja Organisasi. Dengan demikian hipotesis ketiga yang menyatakan bahwa Komunikasi organisasi berpengaruh terhadap kinerja Pegawai Dinas Lingkungan Hidup Kota Makassar dapat dibuktikan

\section{SARAN}

1. Pengembangan Kompetensi SDM Pegawai harus dilakukan dengan tetap berpedoman pada norma kepegawaian yang telah diatur organisasi. Pengembangan kompetensi SDM masih harus ditingkatkan lagi terutama kompetensi teknis dan kompetensi sosial. Disarankan kepada Pimpinan organisasi agar membuka ruang dan kesempatan kepada pegawai dalam mengikuti pendidikan dan latihan untuk mengasah skiil dan kompetensinya.

2. Pemanfaatan teknologi informasi agar memperhatikan kemampuan dari pegawai yang menggunakan berbagai fasilitas penunjang pekerjaan yang menggunakan sarana teknologi informasi. Pegawai yang ditempatka pada bagian tertentu harus memiliki kemampuan pemanfaatan teknologi.

3. Komunikasi organisasi harus dibangun dalam pola-pola yang memberikan ruang kreativitas pegawai, dalam membangun harmonisasi dalam komunikasi baik sesame pegawai, antar pegawai dan pimpinan maupun lintas instansi

\section{DAFTAR PUSTAKA}

Lawasi, E.S. \& Triatmono (2017).Pengaruh komunikasi, motivasi dan kerjasama tim Terhadap peningkatan kinerja karyawan. Jurnal menejemen Universitas Merdeka Malang Vol.5 No.1 2017.

Duwit, F. (2015). The Effect Of Communication Competence, Emotional Intelligence And Cultural Organization To The Performance Of Employees (Studies In Community Empowerment Board And The Government Of Village Raja Ampat In West Papua Province ).Jurnal EMBA Vol.3 No.4 Desember 2015, Hal.130-141

Thompson, G. (1995), Task-Technology Fit and Individual Performance, McGrawHill, New York.

Martin, E. (1999). Managing Information Technology What Managers Need to Know.3rd ed. New Jersey:Pearson Education International.

Maula, F., Rahim, S., \& Lannai, D. (2020). Beberapa Faktor Yang Mempengaruhi Penggunaan DJP Online. CESJ: Center Of Economic Students Journal, 3(1), 1-16.

Rasipan, R. \& Andriyani, M. (2017). Pengaruh Kompetensi Dan Manajemen Teknologi Informasi Terhadap Kualitas Pelayanan Di Kantor Pemerintahan Kecamatan.

Sari, M., Basri, H. \& Indriani, M. (2017).Pengaruh pemanfaatan teknologi informasi, kompetensi aparatur dan komitmen organisasi terhadap kinerja manajerial pengelolaan keuangan pada satuan kerja perangkat kabupaten pemerintah 
daerah Kabupaten aceh jaya. Jurnal Megister Akuntansi Pascasarjana Universitas Syiah KualaVolume 6, No. 2, Mei 2017

Sugiyanto dan Santoso, D. (2018). Analysis of the Effect of Competence, Supporting Facilities of Information Technology and Job Satisfaction as Intervening Variables on HRPerformance.Magister Manajemen Universitas Semarang.

Suhardiyah, M. (2014). Analisis Faktor-Faktor yang Mempengaruhi Kinerja Sistem Informasi Akuntansi (Studi Kasus pada Universitas PGRI Adi Buana Surabaya). Majalah Ekonomi, 18(1).

Wursanto. (2002). Dasar-dasar Ilmu Organisasi, Yogyakarta: Andi Offset. 